\title{
APLIKASI SISTEM PAKAR SKORING TES IQ MENGGUNAKAN ALAT CFIT
}

\author{
J. Angelina Widians ${ }^{1)}$, Irwan Aditya Saputr ${ }^{2)}$ \\ ${ }^{1,2}$ Teknik Informatika, Fakultas Ilmu Komputer dan Teknologi Informasi, Universitas Mulawarman \\ ${ }^{1,2}$ Jl. Barong Tongkok No. 6 Kampus Gn. Kelua, B29, 75127 \\ E-Mail : : angel_widians@yahoo.com ${ }^{1)}$,irwanaditya88@gmail.com ${ }^{2)}$
}

\begin{abstract}
ABSTRAK
Sistem Pakar merupakan suatu bagian dari kecerdasan buatan yang mengandung pengetahuan dan pengalaman yang digunakan untuk memecahkan berbagai masalah, pembuatan aplikasi sistem pakar skoring tes IQ dengan alat CFIT berbasis desktop ini memberikan kemudahan kepada user yang ingin melakukan tes IQ CFIT. Penyajian tes-tes yang dilakukan melalui desktop diharapkan dapat memberi banyak manfaat dan mudah diimplementasikan. Metode yang digunakan dalam penelitian ini adalah metode Forward Chaining untuk menentukan IQ seseorang. Input dari sistem pakar skoring tes IQ dengan alat CFIT ini adalah soal-soal tes IQ yang terdiri dari 50 soal yang telah disediakan. Kemudian proses yang dilakukan adalah dengan menjawab soal-soal yang ada didalam sistem tersebut dengan durasi yang telah ditentukan. Output dari sistem pakar skoring tes IQ dengan alat CFIT ini adalah menentukan IQ seseorang. Dengan adanya sistem ini kita dapat memperkenalkan bahwa memilih metode atau alat tes IQ akan lebih mudah diterapkan dalam memanfaatkan teknologi.
\end{abstract}

Kata Kunci : Sistem pakar, Tes IQ CFIT, Forward Chaining

\section{PENDAHULUAN}

Keberhasilan dan kegagalan seseorang dalam kehidupan baik dalam bidang pekerjaan, maupun kemasyarakatan banyak sekali dipengaruhi oleh sikap dan sifat-sifat kepribadiannya. Namun kegagalan bisa saja terjadi karena sesorang kurang percaya diri pada dirinya sendiri. Pesimis atau hal yang lainnya yang mungkin kurang positif tanpa disadari atau bahkan tidak diketahui sama sekali oleh dirinya akan kepribadiannya seperti apa.

Sistem pakar merupakan salah satu perangkat lunak yang sesuai untuk pemecahan permasalahan ini karena sistem pakar dapat menyajikan dan menggunakan data yang ada pada basis pengetahuan untuk menggantikan sementara keududukan seseorang yang memilik kemampuan dalam memperediksi dan menganalisis kepribadian seseorang.

Dengan mengetahui dan mengerti diri pribadi secara langsung diharapkan dapat memperbaiki kekurangan-kekurangan yang ada pada diri orang tersebut berdasarkan petunjuk dan saran-saran yang diberikan oleh para pakar dalam bidang kepribadianya. Oleh karena itu, dibuatlah sistem yang dapat menirukan keahlian / kepakaran seorang pakar dalam melakukan skoring tes IQ. Sistem tersebut dalam bidang teknologi komputer dinamakan sistem pakar (expert system). Yang mempunyai kelebihan tersendiri dari sistem-sistem yang ada. Kelebihannya yaitu dapat menambah, mengubah dan menghapus soal tergantung kebutuhan dari pakar tersebut. Berdasarkan uraian tersebut, maka dibuatlah sebuah aplikasi sistem yang dapat mendeteksi tingkat IQ seseorang " Sistem Pakar Skoring Tes IQ dengan alat CFIT berbasis Desktop “

\section{BAHAN \& TINJAUN PUSTAKA}

Kecerdasan Buatan (Artificial Intelegent) merupakan salah satu bagian dari ilmu komputer yang membuat agar komputer dapat melakukan pekerjaan seperti yang dilakukan manusia. Kecerdasan buatan memiliki banyak bidang terapan diantaranya Expert Sistem (sistem pakar), Natural Language Processing (pemrosesan bahasa ilmiah), Computer Visio I(mengintrepetasi gambar melalui komputer), Intelligence Computer Aided Instruction (tutor dalam melatih dan mengajar), Speech Recognition (pengenalan ucapan), Robotics and Sensory Sistem (robotika dan sistem sensor).

Sistem pakar adalah sistem berbasis komputer yang menggunakan pengetahuan, fakta, dan teknik penalaran dalam memecahkan masalah yang biasanya hanya dapat dipecahkan oleh seorang pakar dalam bidang tersebut. Pada dasarnya sistem pakar diterapkan untuk mendukung aktifitas pemecahan masalah. Umumnya kecepatan dalam memecahkan masalah pada suatu sistem pakar relative lebih cepat dibandingkan dengan manusia (Kusumadewi, 2003).

Mesin Inferensi merupakan otak dari sebuah sistem pakar dan dikenal juga dengan sebutan control structure atau rule interpreter (dalam sistem pakar berbasis kaidah). Komponen ini berisi mekanisme pola pikir dan penalaran yang digunakan oleh pakar dalam menyelesaikan suatu masalah. Mesin inferensi adalah processor pada sistem pakar yang mencocokkan bagian 
kondisi dari rule yang tersimpan di dalam knowledge base dengan fakta yang tersimpan di working memory. Ada beberapa teknik penalaran yang dapat digunakan salah satunya adalah forward chaining.

Foward chaining merupakan pencocokan fakta atau pernyataan dimulai dari bagian kiri (IF) atau dengan kata lain penalaran dimulai dari fakta terlebih dahulu untuk menguji kebenaran. Metode ini sering disebut data-driven karena mesin inferensi menggunakan informasi yang ditentukan oleh pemakai untuk memindahkan ke seluruh jaringan dari logika „AND ${ }^{\text {ee }}$ dan „OR ${ }^{\text {ce }}$ sampai sebuah terminal ditentukan sebagai objek. Bila mesin inferensi tidak dapat menentukan objek maka akan meminta informasi lain. Aturan (Rule) dimana menentukan objek, membentuk lintasan (path) yang mengarah ke objek. Oleh karena itu, hanya satu cara untuk mencapai suatu objek adalah dengan memenuhi semua aturan [2].

Sistem pakar yang dibangun ini menggunakan penalaran atau inferensi secara runut maju atau forward chaining berdasarkan basis pengetahuan dari seorang pakar psikologi yang paham mengenai test IQ.

Tes CFIT adalah salah satu jenis tes dalam psikologi yang berupa gambar-gambar yang digunakan untuk membedakan tingkat intelegensia, mengukur tingkat kecerdasan, menentukan jenis terapi, serta mengadakan tes kepegawaian. CFIT mengukur intelegensi individu dalam suatu cara yang direncanakan untuk menguragi pengaruh kecakapan verbal dan tingkat pendidikan [3].

CFIT merupakan satu dari sekian tes intelektual yang ada. Selain tes tersebut masih ada tes-tes lain serupa seperti TIU (Tes Intelegensi Umum), TKP (Tes kemampuan dasar), AA (Army alpha), ADKUDAG (Administrasi dan keuangan), serta IST ( Tes Intelegensi ).

Secara sederhana, sebagai bagian dari tes psikolog secara umum, tes ini akan membantu seseorang mengetahui kemampuan orang lain atau dirinya sendiri. 'kemampuan' yang dimaksud disesuaikan dengan kebutuhan tes yang ada. Tes CFIT akan meningkatkan kecerdasan dan intelektual seseorang.

CFIT digunakan untuk mengukur Crystallized Ability (Kemampuan kognitif yang terakumulasikan untuk sejumlah waktu, tersimpan dalam memori jangka panjang, dan dipanggil keluar jika dibutuhkan. Kemampuan ini, didalam perkembangannya, akan mempengaruhi fluid ability. Nilai IQ yang diperoleh dari hasil tes CFIT ini disebut dengan istilah IQ Original, karena nilai tersebut merupakan nilai potensi yang sifatnya bawaan, dan lebih dikarenakan factor usia. Nilai IQ bukan diperoleh karena hasil pengalaman atau proses belajar. Nilai ini masih mungkin berubah dan berkembang sejalan dengan bertambah usianya seseorang. Oleh karena itu, nilai IQ yang diperoleh dari tes ini tidak berhubungan langsung dengan prestasi akademik.

\section{METODE}

Tes CFIT memiliki 4 Subtest. Dimana subtest pertama memiliki 3 soal sebagai contoh bagaimana pengerjaannya dan 13 soal untuk dikerjakan sendiri oleh peserta. Pada subtest pertama waktu yang diberikan untuk mengerjakan adalah 3 menit, sedangkan untuk instruksi waktu yang diberikan adalah 5 menit. Lalu pada subtest yang kedua terdapat 3 soal sebagai contoh dan 14 soal untuk dikerjakan sendiri oleh peserta. Pada substest kedua waktu yang diberikan untuk mengerjakan 4 menit, sedangkan untuk instruksi waktu adalah 5 menit. Untuk subtest ketiga terdapat 3 soal untuk contoh dan 13 soal untuk dikerjakan sendiri oleh peserta tes. Pada subtest ketiga diberikan waktu 3 menit untuk mengerjakan soal, dan 5 menit untuk memberikan instruksi. Lalu pada subtest terakhir yaitu subtest ke empat, terdapat 3 soal untuk contoh dan 10 soal tes untuk dikerjakan sendiri atau tanpa didampingi pengetes. Waktu yang diberikan untuk pengerjaan soal adalah 2,5 menit dan untuk instruksi adalah 5 menit.

Sebelum membuka buku soal silahkan melihat pada lembar jawaban anda paling atas. Silahkan isi identitas anda pada bagian tersebut. Untuk nama, anda bisa mengisikan nama lengkap anda. lalu isi tanggal hari ini dimana hari ini adalah hari anda mengerjakan tes CFIT, lalu isi tanggal lahir anda. Untuk Usia, diisi dengan cara mengurangi tanggal tes dengan tanggal lahir anda. Jika tanggal tesnya adalah tanggal 12 bulan 11 tahun 2013, lalu tanggal lahir anda sebagai contoh tanggal 12 bulan 11 tahun 1994 maka usia anda adalah 19 tahun 10 bulan 0 hari. Untuk nomor bisa anda isikan sesuai nomor yang tertempel pada buku tes anda. Untuk pendidikan normal bisa dikosongkan saja.

Jika identitas anda telah diisi, maka bukalah buku soal anda pada halaman pertama. Lihatlah gambargambar tes berikut. Garis vertikal yang sedikit demi sedikit akan jatuh ke samping kanan anda. Tugas anda disini adalah mencari gambar ke 4 dari 5 gambar yang tersedia pada pilihan jawaban. Maka untuk contoh yang pertama jawabannya adalah "C". Perhatikan contoh pada garis kedua, lihatlah garis yang hitam pada kotak tersebut, makin lama makin turun kebawah seolah-olah seperti tirai yang diturunkan ke bawah. Maka untuk soal ini jawabannya adalah "E". Untuk soal yang ketiga lihatlah gambar-gambar kelopak daun makin lama makin bertambah 1 helai daun dan dimulai dari atas terus kekanan. Maka untuk contoh soal ini jawabannya adalah "E". Berikanlah tanda silang pada jawaban anda pada lembar jawaban yang telah tersedia. Jika anda ingin mengganti jawaban anda maka berikanlah tanda sama dengan pada jawaban anda sebelumnya lalu berikanlah tanda silang pada jawaban yang anda anggap benar. Jika anda ingin kembali pada jawabannya sebelumnya maka berikanlah lingkaran pada jawaban yang anda anggap paling benar dan berikanlah tanda sama dengan pada jawaban anda sebelumnya.

Contoh Soal :

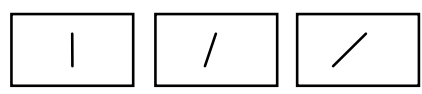

Contoh Pilihan Jawaban :
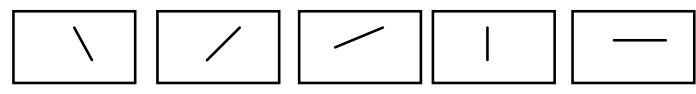

Untuk cara mencari menilai atau mencari skor pada tes CFIT adalah dengan menjumlahkan semua jawaban benar pada subtest 1, 2, 3, dan 4. Lalu 
jawaban benar tersebut dikalikan 1. Berikut contoh proses skoring tes CFIT sebagai berikut :

a. Identitas

Nama : Ibnu Haldum

Nim

: 201210230311381

Jenis Kelamin : Laki-laki

Tanggal Tes : 12-11-2016

Tanggal Lahir : 24-05-1995

Umur : 21 Tahun

b. Hasil Tes

Jumlah jawaban benar pada subtest pertama $=\mathbf{6}$

Jumlah jawaban benar pada subtest kedua $=\mathbf{6}$

Jumlah jawaban benar pada subtest ketiga $=\mathbf{6}$

Jumlah jawaban benar pada subtest keempat $=\mathbf{4}$

Rumus mencari RS=Jumlah Jawaban Benar $x 1$

$$
\begin{aligned}
& =(6+6+6+4) \times 1 \\
& =22 \times 1 \\
& =\mathbf{2 2}
\end{aligned}
$$

Maka, total Raw Score ( RS ) user adalah 22.

Untuk mengetahui klasifikasi, kita harus melihat pada tabel klasifikasi CFIT. Jadi, raw score kita telah dapatkan sebelumnya belum bisa dikatakan merupakan IQ seseorang. Kita harus mencocokkan terlebih dahulu raw score tersebut dengan umur user. Hal ini bisa dilihat pada tabel klasifikasi. Adapun tabel klasifikasinya adalah sebagai berikut:

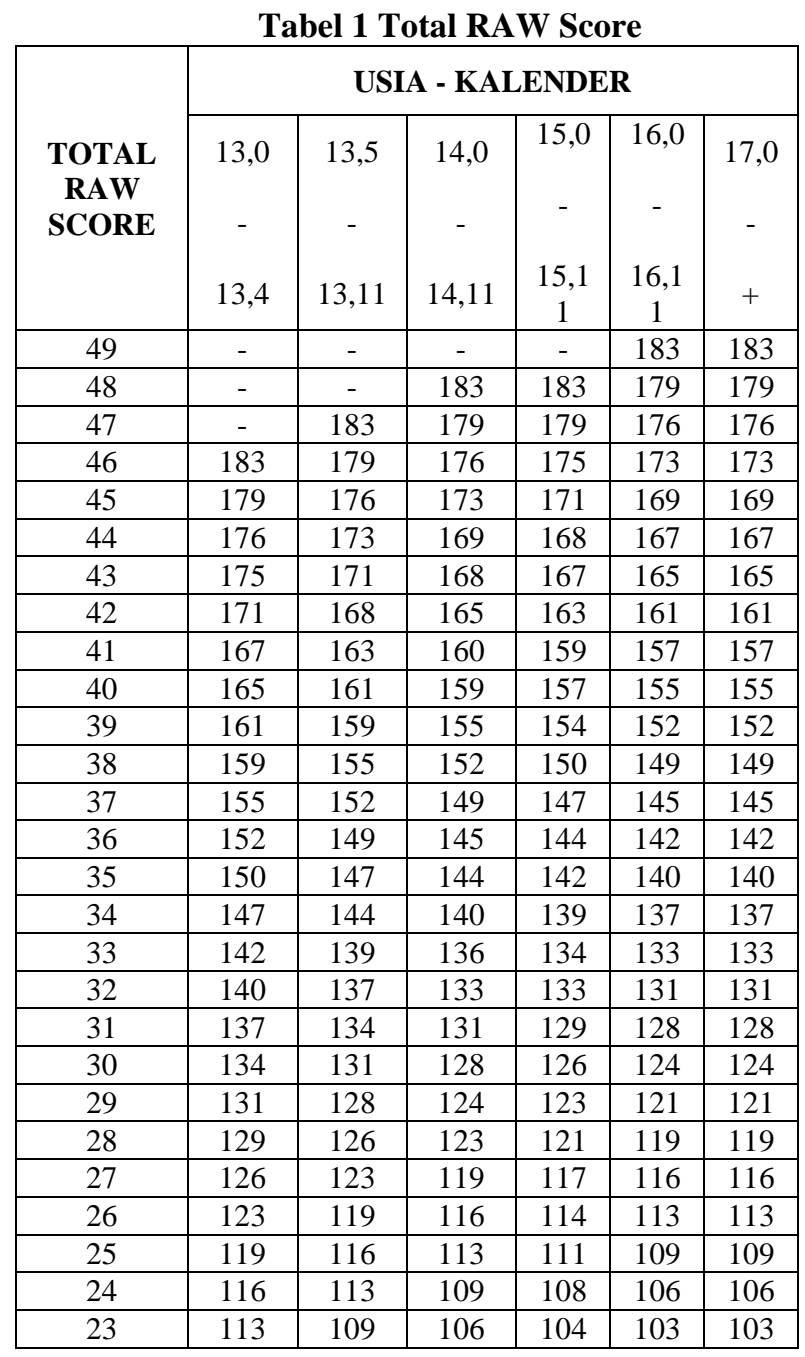

\begin{tabular}{|c|c|c|c|c|c|c|}
\hline 22 & 109 & 106 & 103 & 101 & 100 & 100 \\
\hline 21 & 106 & 103 & 100 & 98 & 96 & 96 \\
\hline 20 & 104 & 101 & 98 & 96 & 94 & 94 \\
\hline 19 & 101 & 98 & 94 & 93 & 91 & 91 \\
\hline 18 & 98 & 93 & 91 & 89 & 88 & 88 \\
\hline 17 & 94 & 91 & 88 & 86 & 85 & 85 \\
\hline 16 & 91 & 88 & 85 & 83 & 81 & 81 \\
\hline 15 & 88 & 85 & 81 & 80 & 78 & 78 \\
\hline 14 & 85 & 81 & 78 & 76 & 75 & 75 \\
\hline 13 & 81 & 78 & 75 & 73 & 72 & 72 \\
\hline 12 & 80 & 76 & 73 & 72 & 70 & 70 \\
\hline 11 & 76 & 73 & 70 & 68 & 67 & 67 \\
\hline 10 & 75 & 72 & 68 & 65 & 65 & 65 \\
\hline 9 & 70 & 67 & 63 & 62 & 60 & 60 \\
\hline 8 & 67 & 63 & 60 & 58 & 57 & 57 \\
\hline 7 & 63 & 60 & 57 & 56 & 55 & 55 \\
\hline 6 & 60 & 57 & 53 & 53 & 52 & 52 \\
\hline 5 & 57 & 53 & 52 & 51 & 48 & 48 \\
\hline 4 & 55 & 54 & 51 & 50 & 47 & 47 \\
\hline 3 & 53 & 52 & 48 & 47 & 45 & 45 \\
\hline 2 & 52 & 51 & 47 & 46 & 43 & 43 \\
\hline 1 & 50 & 50 & 46 & 45 & 40 & 40 \\
\hline 0 & 0 & 0 & 0 & 0 & 0 & 0 \\
\hline & & & & & & \\
\hline
\end{tabular}

Pada Tabel 1 Total RAW Score menunjukkan umur user dengan raw score yang didapatkannya. Usia user adalah 21 Tahun, dan raw score yang didapat adalah 22. maka diketahui IQ user adalah $\mathbf{1 0 0}$.

\begin{tabular}{|c|c|c|c|c|c|c|}
\hline 22 & 109 & 106 & 103 & 101 & 100 & 100 \\
\hline$\downarrow$ \\
Raw Score User
\end{tabular}
R

Karena usia user 21 Tahun, maka usia user bisa bisa dilihat pada umur 17 tahun keatas

Tabel 2. Klasifikasi IQ CFIT

\begin{tabular}{|c|l|}
\hline Skor IQ & \multicolumn{1}{|c|}{ Kategori } \\
\hline$>170$ & Genius/Jenius \\
\hline $140-169$ & Very Superior/Sangat Cerdas \\
\hline $120-139$ & Superior/Cerdas \\
\hline $110-119$ & High Average/Diatas Rata-rata \\
\hline $\mathbf{9 0 - 1 0 9}$ & Average/ Rata-rata \\
\hline $\mathbf{8 0 - 8 9}$ & $\begin{array}{l}\text { Low Average/Dibawah Rata- } \\
\text { rata }\end{array}$ \\
\hline $70-79$ & Borderline \\
\hline$<70$ & Mentally Defective \\
\hline
\end{tabular}

Pada Tabel 2. Tabel Klasifikasi IQ CFIT diatas maka user masuk kedalam klasifikasi IQ rata-rata atau Average.

Contoh :

R1: IF A and C, THEN E

R2: IF D and C, THEN F

R3: IF B and E, THEN F

R4: IF B, THEN C

R5: IF F, THEN G

Fakta nya adalah: A benar dan B benar Langkah -langkahnya:

1. Dimulai dari R1 Karena C dan E tidak diketahui maka tidak diambil kesimpulan. Pencocokan lanjut 
di R2, ternyata di R2 juga tidak diambilkesimpulan. Lakukan hal sama pada R3, kemudian pada R4 bernilai benar karena B diketahui benar.

2. Selanjutnya ke R5, namun tidak dapat diambil kesimpulan. Lalu kembali lagi ke atas, R1 bernilai benar karena $\mathrm{A}$ benar dan $\mathrm{C}$ benar maka $\mathrm{F}$ benar.

3. Lalu ke R2, karena D belum diketahui kebenarannya makanya tidak dapat diambil kesimpulan.

4. Lanjut pada R3, karena B dan F benar maka E juga benar.

5. Selanjutnya pada R5, karena $F$ benar maka G benar. Sehingga dengan demikian $G$ adalah kesimpulannya.

Demikian pohon Forward Chaining dapat dilihat pada gambar :

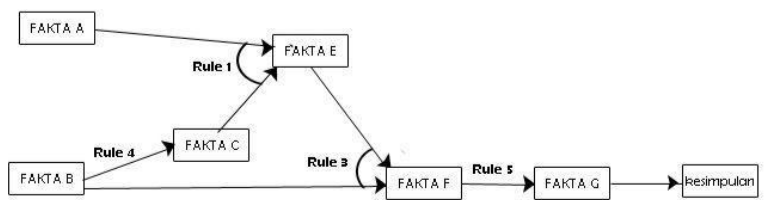

Gambar 1. Diagram Pohon Forward Chaining

\section{IMPLEMENTASI}

Hasil implementasi berdasarkan analisis dan perancangan adalah sebagai berikut :

\subsection{Hasil Penelitian}

Hasil penelitian sistem pakar skoring tes IQ dengan alat CFIT berbasis desktop yang telah didapatkan kemudian diambil untuk dibandingkan dengan perhitungan manual yang telah diketahui. Berikut langkah - langkah perhitungan :

1. Pemilihan Klasifikasi Umur

2. Perhitungan Raw Score dari Jumlah Jawaban Benar

3. Pemilihan Skor IQ

4. Pemilihan Klasifikasi Umur

Tabel 3. Data User

\begin{tabular}{|c|c|c|}
\hline Nama & Tanggal Lahir & Usia \\
\hline Hadi & $25 / 05 / 1994$ & 22 \\
\hline Ardiati & $19 / 10 / 1994$ & 21 \\
\hline Bayu & $21 / 09 / 1994$ & 22 \\
\hline
\end{tabular}

Pada Tahap ini sistem melakukan perhitungan antara selisih waktu saat ini dengan waktu berupa tanggal lahir yang diberikan user, kemudian didapatkan umur user dari jumlah selisih hari yang didapatkan. Pada data hasil penelitian user Hadi Nur Rahman memberikan input tanggal lahir berupa 22/05/1994 kemudian diketahui umur user yaitu 22 tahun sehingga user masuk pada klasifikasi umur lebih dari 17. Kemudian user yang bernama Ardiati Oktavianur memberikan input tanggal lahir 19/10/1994 kemudian diketahui umur user yaitu 21 tahun sehingga user masuk pada klasifikasi lebih dari 17. Dan user yang bernama Bayu Firmansyah memberikan input tanggal lahir 21/09/1994 sehingga diketahui umur user yaitu 21 tahun dan masuk pada klasifikasi umur lebih dari 17 tahun.

5. Perhitungan Raw Score dari Jumlah Jawaban Benar

Pada tahap ini dilakukan penjumlahan jawaban benar untuk mendapatkan raw score. Berikut data yang telah didapat :

Tabel 4. Perhitungan Raw Score Jawaban Benar

\begin{tabular}{|c|c|c|c|}
\hline Nama & $\begin{array}{c}\text { Jumlah } \\
\text { Pertanyaan }\end{array}$ & $\begin{array}{c}\text { Jawaban } \\
\text { salah }\end{array}$ & $\begin{array}{c}\text { Raw Score } \\
\text { (Jawaban } \\
\text { Benar) }\end{array}$ \\
\hline Hadi & 50 & 16 & 34 \\
\hline Ardiati & 50 & 26 & 24 \\
\hline Bayu & 50 & 20 & 30 \\
\hline
\end{tabular}

Pada Tabel 4 menunjukkan bahwa user yang bernama Hadi mendapatkan Raw Score 34 dari 50 pertanyaan. Ardiati mendapatkan Raw Score 24 dari 50 pertnyaan dan Bayu mendapatkan Raw Score 30 dari 50 pertanyaan.

\section{Pemilihan Skor IQ}

Tabel 5. Pemilihan Skor IQ

\begin{tabular}{|c|c|c|c|c|c|c|c|}
\hline \multirow[b]{2}{*}{ Nama } & \multirow[b]{2}{*}{$\begin{array}{c}\text { Total } \\
\text { Raw } \\
\text { Score }\end{array}$} & \multicolumn{6}{|c|}{ Usia } \\
\hline & & $\begin{array}{c}13,0 \\
- \\
13,4\end{array}$ & $\begin{array}{c}13,5 \\
- \\
13,1 \\
1\end{array}$ & $\begin{array}{c}14,0 \\
- \\
14,1 \\
1\end{array}$ & $\begin{array}{c}15,0 \\
- \\
15,1 \\
1\end{array}$ & $\begin{array}{c}16,0 \\
- \\
16,1 \\
1\end{array}$ & $\begin{array}{c}17,0 \\
- \\
+\end{array}$ \\
\hline Hadi & 34 & 147 & 144 & 140 & 139 & 137 & 137 \\
\hline Ardiati & 24 & 116 & 113 & 109 & 108 & 106 & 106 \\
\hline Bayu & 30 & 134 & 131 & 128 & 126 & 124 & 124 \\
\hline
\end{tabular}

Dari Tabel 5. Pemilihan skor IQ Hadi dengan usia 22 tahun memiliki total Raw Score 34 maka Hadi masuk kategori 17 tahun keatas dengan IQ 137. Ardiati dengan usia 21 tahun memiliki total Raw Score 24 maka Ardiati masuk kategori 17 tahun keatas dengan IQ 106. Bayu dengan usia 22 tahun memiliki total Raw Score 30 maka Bayu masuk kategori 17 tahun ketas dengan IQ 124.

\subsection{Implementasi Program}

Implementasi berbasis desktop dibuat berdasarkan desain yang telah direncanakan dan menggunakan bahasa pemrograman Java. Selanjutnya akan dijelaskan lebih detail mengenai implementasi antarmuka pada perancangan sistem pakar skoring tes IQ dengan alat CFIT yang telah dibuat.

1. Halaman Login

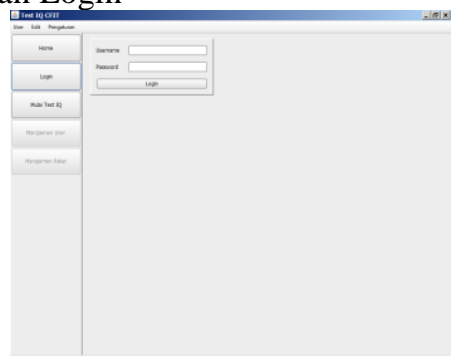

Gambar 2. Halaman Login

Pada gambar 2. halaman login terdapat form yang 
di isi oleh pengguna aplikasi yang telah terdaftar untuk masuk ke dalam sistem. Ketika seorang administrator berhasil login, administrator dapat mengakses halaman manajemen user, dan manajemen pakar yang sebelumnya tidak dapat diakses.

2. Halaman Beranda

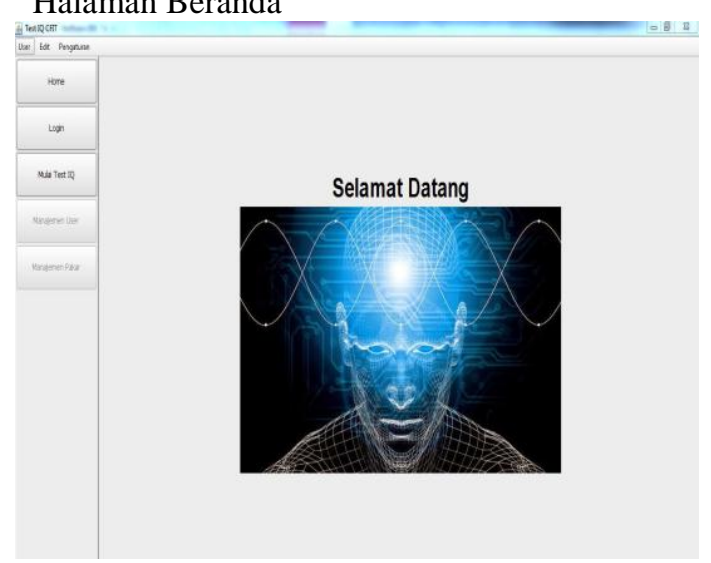

Gambar 3 Halaman Beranda

Pada gambar 3 Halaman beranda berisi tentang sambutan terhadap pengguna sistem pakar skoring tes IQ dengan alat CFIT.

3. HalamanSkoring Tes IQ

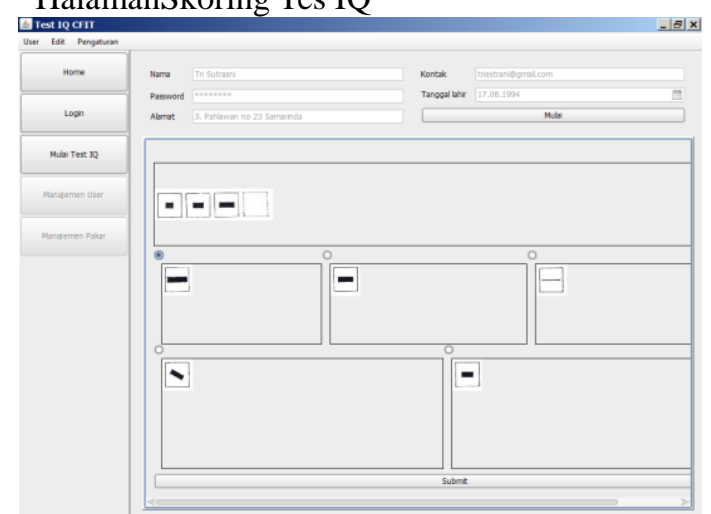

Gambar 4. Halaman Skoring Tes IQ

Pada gambar 4. pengguna aplikasi memberikan input berupa jawaban soal test IQ yang ditampilkan. Setelah data yang diberikan pengguna aplikasi lengkap, sistem akan mulai melakukan perhitungan dan pengguna sistem akan dialihkan ke halaman hasil skoring test IQ.

4. Halaman Hasil Skoring Tes IQ

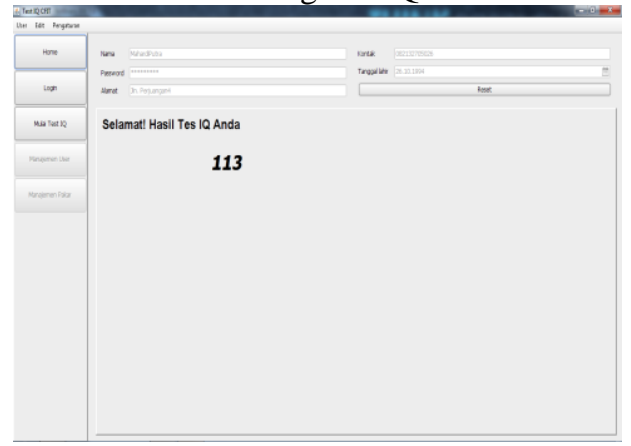

Gambar 5. Halaman Hasil Skoring Tes IQ

Pada gambar 5. menampilkan hasil perhitungan setelah sistem melakukan perbandingan terhadap raw score dan table norma yang telah disediakan sehingga pengguna aplikasi dapat melihat hasil perhitungan yang telah dilakukan.

Berdasarkan hasil implementasi sistem pakar skoring tes IQ dengan alat CFIT berbasis desktop, adminstrator bertugas untuk mengupload soal, dan melihat atau menghapus data user. Semua pengguna sistem dapat melakukan skoring tes IQ setelah melakukan pendaftaran, dan data user akan disimpan oleh sistem untuk diakses kembali dalam manajemen user.

Perhitungan yang dilakukan oleh sistem menggunakan metode forward chaining dilakukan setelah sistem menjumlahkan jawaban benar dari user. Forward chaining digunakan untuk mencari score $I Q$ user berdasarkan jumlah jawaban benar melalui tabel norma yang telah diberikan oleh pakar.

\section{KESIMPULAN}

Dari semua uraian penelitian ini dapat diambil beberapa kesimpulan antara lain :

1. Aplikasi sistem pakar skoring tes IQ dengan alat CFIT menggunakan metode Forward Chaining ini dibuat sebagai alat bantu untuk memudahkan dan menentukan berapa score tes IQ seseorang.

2. Sistem pakar yang dibangun ini dengan mudah seorang admin menambahkan, menghapus atau mengubah data-data soal yang sudah ada berdasarkan pengetahuan dari seorang pakar. Selain itu dengan mudah seorang user mengerjakan soal-soal tes CFIT tanpa harus mengerjakan secara manual

\section{SARAN}

Aplikasi sistem pakar skoring tes IQ dengan alat CFIT ini masih bisa dikembangkan menggunakan sistem operasi android, windows mobile, maupun ios untuk mencakup ruang lingkup masyarakat yang lebih luas serta mengikuti kemajuan teknologi.

\section{DAFTAR PUSTAKA}

Kusumadewi, S., "Artificial Intellegence ( Teknik dan Aplikasinya) “, Graha Ilmu, Yogyakarta 2003.

Giarratano,J. Gary,R., "Expert System : Principles and Programming", Boston, PWS Publishing Company, 1994.

Cattel, R.B dan Butcher, H.J. , "Creativity and Personality. Vernon, P.E. Creativity : Selected Readings", Pinguin Books, Baltimore, 1989 